DOI: $\underline{10.35619 / \text { iiu.v1i13.342 }}$

Гронь Лариса

кандидат педагогічних наук, доцент, доцент кафедри методики викладання іноземних мов Рівненського державного гуманітарного університету, м. Рівне, Україна ORCID: 0000-0002-8115-9798 e-mail: larisa.gron@gmail.com

Середюк Лариса кандидат педагогічних наук, доцент, професор кафедри практики німецької та французької мов Рівненського державного гуманітарного університету,

м. Рівне, Україна ORCID: 0000-0001-5680-564X e-mail: larisa-seredyuk@ukr.net

\title{
ФОРМУВАННЯ УСНОМОВЛЕННСВИХ УМІНЬ У ФОРМІ РОЗДУМУ МАЙБУТНІХ УЧИТЕЛІВ ІНОЗЕМНОЇ МОВИ
}

Анотація. Стаття актуалізує одну 3 нагальних проблем навчання іноземної мови на спеціальних факультетах закладів вищої освіти навчання усного мовлення, зокрема формування усномовленнєвих умінь у формі найскладнішого комунікативного типу мовлення - роздуму. Зазначається, що в межах компетентісного підходу до навчання усне зв'язне логічне мовлення є одним із важливих компонентів спеціальної (мовної) професійно-орієнтованої підготовленості майбутніх учителів іноземної мови.

Монолог-роздум розглядається як складне мовленнєве вміння спонукати співрозмовника до певних дій та переконати його у чомусь; навести докази «за» чи «проти» певної дії/фактів; висловлюватись самостійно, творчо, критично мислити та розмірковувати на задані теми; як засіб активізації усної іншомовної комунікативної діяльності студентів.

У роботі проаналізовано поняття «монолог-роздум», його основні композиційні (зачин, доказ, висновок) та лінгвістичні характеристики, етапи організації процесу формування усномовленнєвих умінь роздуму.

Запропоновано алгоритм роботи та комплекс вправ з навчання усного монологу - роздуму, який сприятиме активізації та інтенсифікації процесу формування іншомовної усномовленнєвої підготовки майбутніх фахівців.

Ключові слова: іншомовна усномовленнєва компетенція, монологічне мовлення, монолог-роздум, етапи формування умінь роздуму, комплекс вправ.

(С) Гронь Л., Середюк Л., 2021 


\section{Інноватика у вихованні. Випуск 13.Том 1. 2021.}

Постановка проблеми. Процес інтеграції України в європейський освітній простір зумовив низку кардинальних змін у системі вищої професійної освіти. Уведення нових державних освітніх професійних стандартів у межах компетентісного підходу до навчання висуває нові вимоги до спеціальної (мовної) професійно-орієнтованої підготовленості студентів мовних спеціальностей - майбутніх учителів іноземної мови.

У Програмі для закладів вищої освіти, які здійснюють підготовку фахівців 3 англійської мови, зазначається, що випускники мовних спеціальностей повинні висловлюватися 3 необхідним ступенем деталізованості й тематичної складності, демонструючи вільне володіння прийомами структурної побудови тексту, засобами зв'язності та цілісності на суперсинтаксичному рівні (Ніколаєва, Соловей, Головач та ін., 2001, с. 2). Як бачимо, формування та розвиток іншомовної компетенції в усному монологічному мовленні $є$ одним із важливих компонентів майбутньої професійної діяльності здобувачів, оскільки зв'язне логічне мовлення $\epsilon$ однією 3 важливих складових критичного мислення, розвитку якому в сучасному освітньому процесі відводиться пріоритетне значення.

Відомо, що монолог - це безпосередньо спрямований до співрозмовника чи аудиторії організаційний вид усного мовлення, який передбачає висловлювання однієї особи. «Залежно від комунікативної функції та характеру логіко-синтаксичних зв'язків між реченнями розрізняють такі основні типи монологічних висловлювань: опис, розповідь і роздум (міркування)» (Ніколаєва, 2002).

Роздум пов'язаний з передачею змістовно-концептуальної інформації і вважається найскладнішим комунікативним типом мовлення, оскільки спирається на умовиводи як процес мислення, в ході якого на основі вихідного смислу (судження) доводяться певні положення, формулюється висновок. Цей тип мовлення має специфічну мовну структуру, яка залежить від логічної основи роздуму і від смислу висловлювання, i характеризується причинно-наслідковими зв'язками.

Таким чином, монолог у формі роздуму - це складне мовленнєве вміння висловлюватись самостійно, творчо, критично мислити та розмірковувати на задані теми.

Аналіз останніх досліджень 3 проблеми. Проблема навчання іншомовного монологічного мовлення не $\epsilon$ новою і одержала розробку у роботах таких відомих методистів, як С. Гапонова, Н. Гез, Л. Калініна, А. Климентенко, Л. Лазаркевич, С. Ніколаєва, Ю. Пассов, В. Пащук, I. Самойлюкевич, В. Скалкін, Г. Уайзер, С. Шатілов та ін.

Названі автори зробили помітний внесок у вирішення проблеми оволодіння усним монологічним мовленням, однак тема залишається актуальною. Про недостатню розробленість проблеми свідчить, перш за все, стан мовленнєвої підготовки випускників мовних спеціальностей. Монологічне мовлення студентів як молодших, так і старших курсів не відзначається змістовністю, логічністю, оригінальністю, критичністю, емоційністю тощо. Найчастіше монологічні висловлювання 


\section{Інноватика у вихованні. Випуск 13.Том 1. 2021.}

характеризуються відсутністю важливих деталей, використанням випадкових слів оригіналу, недостатньою зв'язністю між реченнями або їі відсутністю, порушеннями логічного викладу матеріалу, недостатньою аргументованістю і т. ін. Вказані недоліки, на наш погляд, потребують якісно нових підходів до процесу формування іншомовної компетенції в усному монологічному мовленні, зокрема у формі роздуму.

Мета статті - описати алгоритм роботи та комплекс вправ з навчання усного монологу - роздуму.

Виклад основного матеріалу дослідження. Виходячи 3 основних характеристик монологічного мовлення, як-от односторонній характер, контекстність, поєднання елементів підготовленого та непідготовленого мовлення, зв'язність, логічна послідовність, тематичність, ми схиляємось до думки, що формування усномовленнєвих умінь роздуму доцільно здійснювати на текстовій основі (дедуктивним методом), за умови, що вихідною одиницею навчання є текст. Такий підхід має низку переваг. Текст-зразок моделює комунікативну ситуацію, ретельно відібрані автентичні тексти мають високий ступінь інформативності і слугують мовною, мовленнєвою та композиційною опорами, водночас є матеріалом для подальших роздумів на тему, окреслену в тексті.

Ефективною базою для розвитку вмінь монологічного висловлювання у формі роздуму можуть бути такі тексти: монологи-роздуми та статті різної проблематики (економічної, соціальної, екологічної і т. ін.) 3 елементами роздуму, ece (For and Against Essays, Opinion Essays, Points to consider essays) тощо. Під час роботи з такими текстами формулюються завдання: вичленення теми, основних проблем, представлення своїх власних ідей, аргументів та висновків. Отже, текст є об'єктом аналізу, а також можливим прикладом-зразком для побудови власного монологуроздуму.

Якщо навчання роздуму здійснювати на текстовій основі, важливою ланкою роботи $є$ ознайомлення студентів з структурними особливостями аргументативного монологічного висловлювання.

Що ж до композиції, то чітко виділяються три частини: зачин (положення, тема, теза і т. ін.), доказ (аргументація), висновок (підсумок, узагальнення). Теза є головною, провідною у смисловому та структурному відношенні частиною роздуму, який ведеться 3 метою досягнення висновку (Фроликова, 2011, с. 18). У частині доказу розкривається проблема, наводяться аргументи і приклади, а також інші точки зору на окреслену проблему. Основна частина висловлювання повинна плавно підводити до узагальнення. У підсумку заключенні необхідно зробити аргументований висновок теми.

Важливу роль в структурній організації роздуму відіграють засоби зв'язку, насамперед синтаксичні. До них відносяться сполучники (сурядні і підрядні), сполучникові прислівники, вказівні займенники, прислівники, інфінітивні звороти зі значенням причини і т. ін. 


\section{Інноватика у вихованні. Випуск 13.Том 1. 2021.}

Зачин являє собою стверджувальне або заперечне судження про якийсь предмет, явище. У окремих випадках він формулюється у формі запитання, на яке дається відповідь. При переході від тези до доказів функцію засобів зв'язку може виконувати запитання або твердження. Для доказів використовуються факти, які часто поєднуються один з одним словами, що позначають порядок руху думок у числовій послідовності (first, secondly), словосполученнями (the most important, the main cause). Якщо, як доказ аргументу, використовується приклад, він уводиться за допомогою скрепу «for example». Для доказів типу загальновідомого знання характерне вживання займенників (everyone, everybody, nobody), a також іменників у поєднанні з дієсловами, які мають у своїй семантиці оціночність. Умовні докази оформляються як складнопідрядні речення 3 підрядними умови зі сполучником «іf».

Докази типу припущення вводяться словами 3 гіпотетичною модальністю: maybe, perhaps. Для аргументації/доказу мовець повинен запропонувати можливі шляхи вирішення проблеми, аргументувати свою точку зору, вживаючи такі фрази і кліше: One / another / a further / the main / the greatest / the first (dis-)advantage of..., To begin with... / First of all / Secondly... / Thirdly... / Finally / After this / that... / Afterwards / Then / Next...), What is more... / Furthermore... / In addition to this... / Moreover... / Besides... / Not to mention the fact that..., Because / owing to the fact that... / Due to the fact that... / On the grounds that... / since... / For this reason), Thus... / consequently... / as a result...), So that... / so as to... / in order to... / in case... / with the purpose of..., For instance... / for example... / Such as... / like...), Yet / however / nevertheless / but / even / so / still / although... / Even though... / In spite of the fact that....

При переході від доказу до висновку вживаються вислови: «I'm sure, I came to the conclusion». У висновку мовець підводить стислий підсумок, який найчастіше всього вводиться модальними скрепами (So..., That is why..., In conclusion..., To sum up..., For the above mentioned reasons..., All things considered..., Finally..., Lastly..., Taking everything into account / consideration..., Therefore I feel that...).

Для формування уміння стисло, чітко визначити проблему, висловити власне ставлення до неї, студентам необхідно оволодіти такими розмовними формулами і кліше: To start / to begin with I'd like to say / to mention..., I'd like to say a few words..., It's true that..., In my opinion / view / I think, it is very important..., To my way of thinking..., I am convinced / I believe that..., It seems to me that..., I am absolutely sure that..., It makes me..., As far as I know..., People often claim that..., In general..., As a rule...).

Мовленнєві завдання для формування умінь аргументованого висловлювання передбачають виконання таких мовленнєвих дій: спонукати співрозмовника до певних дій та переконати його у чомусь; навести докази «за» чи «проти» певної дії/фактів і здійснюються у три етапи. 


\section{Інноватика у вихованні. Випуск 13.Том 1. 2021.}

На дотекстовому етапі необхідно виконати низку підготовчих мовних і умовно-мовленнєвих вправ, спрямованих на засвоєння та активізацію лексичних одиниць, типових для усного монологічного мовлення, а саме розмовних формул і кліше, вставних словосполучень, речень, різноманітних засобів зв'язку, які не тільки допомагають оформляти монолог-роздум, а й сприяють більш плавному процесу його продукування.

Наведемо приклади орієнтовних завдань у таких вправах: з'єднайте частини складних речень, змінивши засіб зв'язку; прочитайте твердження і висловіть свою думку, використовуючи запропоновані вирази; доповніть роздум словами або словосполученнями, що слугують для зв'язку його частин; об'єднайте запропоновані твердження, використовуючи запропоновані слова; утворіть з двох речень одне складнопідрядне тощо.

Метою текстового (аналітико-синтетичного) етапу навчання монологу-роздуму є сприйняття прослуханого чи прочитаного тексту, його розуміння, запам'ятовування його змісту, мовного матеріалу та композиції. На цьому етапі здійснюється обумовлений комунікативним завданням та ситуаційно задум висловлювання, вибір мовних засобів, реалізуються парадигматичні i синтагматичні зв'язки слів. Для планування, програмування власного висловлювання студенти повинні виконати умовно-мовленнєві вправи, які реалізуються у таких завданнях: прочитайте текст, складіть план у вигляді запитань; прочитайте текст, розмістіть запропоновані словосполучення в хронологічній/логічній послідовності; виділіть слова (словосполучення чи речення), які несуть важливу (ключову) інформацію; сформулюйте ключову думку кожного абзацу; визначте слово (словосполучення), яке найкраще передає зміст тексту (частини тексту); розташуйте пункти плану відповідно до логіки викладу матеріалу в тексті; виділіть тезу, аргументи і висновок у прочитаному тексті; дайте відповіді на запитання до тексту тощо.

Під час роботи з текстовим матеріалом необхідно розвивати вміння оцінювати, відбирати і групувати факти й аргументи згідно з власною точкою зору. Для формування названих умінь виконуються такі групи вправ:

a) вправи, спрямовані на формування вміння будувати узагальнююче висловлювання: відтворіть інформацію, яка узагальнює основний зміст висловлювання; виділіть основну думку на початку, в середині і в кінці тексту-зразка; узагальніть висловлювання в одному реченні; перегляньте текст і назвіть слова, які вживаються для узагальнення його змісту; прочитайте наведені монологи-роздуми з однієї проблеми, підсумуйте загальні і різні думки; прослухайте текст, підкресліть правильні твердження, підсумуйте отримані відомості декількома реченнями; розкрийте запропоновану тезу (пункт плану), підберіть до неї відповідний мовний матеріал з тексту і т. ін;

б) вправи, спрямовані на формування вміння виділяти низку проблем, пов'язаних з основною проблемою, відбирати факти, характеристики: виділіть ключові проблеми тексту; прочитайте висловлювання і виділіть 3 


\section{Інноватика у вихованні. Випуск 13.Том 1. 2021.}

низки запропонованих питань ті, які можуть підніматись при обговоренні цієї проблеми; знайдіть в тексті факти, які автор вважає позитивними (негативними);

в) вправи, спрямовані на формування вміння вичленяти факти з тексту для аргументації проблеми (тези), яка обговорюється: встановіть зв'язки між основною проблемою тексту та аргументами, які доводять його справедливість; виділіть проблемне ключове речення 3 тексту; наведіть аргументи до запропонованої проблеми 3 урахуванням сказаного учасниками дискусії; висловіть свою думку і обгрунтуйте іiі за допомогою фактів/прикладів/порівнянь; наведіть факти (приклади), що підтверджують...; виберіть один із висловів та доповніть його аргументами («за» і «проти»); що ви думаєте про...? Аргументуйте свою думку;

г) вправи, спрямовані на формування вміння робити висновки 3 тексту: відтворіть запропонований монолог, завершуючи його реченням, що виражає вашу власну точку зору; закінчіть речення, які підсумовують сказане кожним учасником дискусії; які приклади можна навести, аби прийти до наступних висновків...?; які висновки можуть бути зроблені на основі нижченаведених фактів ...?

На післятекстовому (контрольно-виконавчому) етапі пропонуються комунікативні вправи, спрямовані на формування вмінь самостійного (творчого) аргументативного монологічного висловлювання у зв'язку зі змістом тексту-зразка, здійснюється логічна побудова роздуму згідно із задумом.

Вправи цього етапу спрямовані на формування таких важливих умінь як уміння висловлювати свою точку зору у зв'язку з прочитаним чи прослуханим, за запропонованою тематичною навчально-мовленнєвою ситуацією, у зв'язку з проблематикою тексту і реалізуються у таких завданнях: довести тезу; пояснити одну із точок зору за вибором; скласти своє власне висловлювання за текстом-зразком, змінивши комунікативний намір; придумати кінцівку оповідання і обгрунтувати свою точку зору фактами 3 тексту-зразка; побудувати власне висловлювання за цитатою, прислів'ям; виступити на конференції з певної проблеми; висловити свою точку зору на проблему; підготувати проєкт з теми.

Це завершальний, продуктивний етап розвитку умінь монологу-роздуму, на якому велику роль відіграють опори, що використовуються найперше для послідовної і логічної побудови структури висловлювання. Оптимальною опорою побудови монологічного висловлювання у формі роздуму щодо структурного моделювання може бути універсальний схематичний план, який легко дозволить студентам запам'ятати структуру роздуму, і згодом повністю перейти до творчих самостійних висловлювань.

Він повинен містити такі обов'язкові компоненти:

1) Маке an introduction/state the problem. Start by saying what the current situation is introducing the debate (What is the problem? What has caused it?).

2) Express your personal opinion. Talk about the advantages or several reasons for your opinion. 
3) Express an opposing opinion. Give disadvantages or reasons for this opposing opinion.

4) Explain why you don't agree with the opposing opinion.

5) Make a conclusion restating your position (What would / could it result in? What are your arguments "for" and "against"? What are the reasons and examples? How can you summarise your opinion?)

Висновки і перспективи подальших розвідок. Як засвідчує практика, запропонований комплекс вправ дозволяє поступово i цілеспрямовано формувати і розвивати вміння побудови монологічного висловлювання у формі роздуму з частковою опорою на текст або план, а згодом логічно і послідовно будувати власний монолог-роздум на запропоновану тему.

Подальшу розробку цієї проблеми ми вбачаємо у встановленні й описі критеріїв оцінювання рівня сформованості умінь майбутніх учителів самостійно будувати власний монолог-роздум іноземною мовою.

\section{СПИСОК ВИКОРИСТАНИХ ДЖЕРЕЛ}

Ніколаєва, С., Соловей, М., Головач, Ю. та ін. (2001). Програма з англійської мови для університетів, інститутів (n'ятирічний курс навчання): Проект. Київ. держ. лінгв. ун-т та ін. 245 с.

Ніколаєва, С. (2002). Методика викладання іноземних мов у середніх навчальних закладах: Підручник. Вид. 2-е, випр. і перероб. / Кол. авт. під керівн. С. Ю. Ніколаєвої. К.: Ленвіт, 2002. 328 с.

Фроликова, Е. (2011). Необходимость совершенствования обучения монологическому высказыванию на английском языке в школе и вузе. Иностранные языки в школе. № 2. СС.15-20.

\section{REFERENCES}

Nikolaieva, S., Solovei, M., Holovach, Yu. ta in. (2001). Prohrama $z$ anhliiskoi movy dlia universytetiv, instytutiv (piatyrichnyi kurs navchannia. [English language program for universities, institutes (five-year course of study)]: Proekt. Kyiv. derzh. linhv. un-t ta in. 245 s. [in Ukrainian].

Nikolaieva, S. (2002). Metodyka vykladannia inozemnykh mov u serednikh navchalnykh zakladakh [Methods of teaching foreign languages in secondary schools]: Pidruchnyk. Vyd. 2-e, vypr. i pererob. / Kol. avt. pid kerivn. S. Yu. Nikolaievoi. K.: Lenvit, 2002. 328 s. [in Ukrainian].

Frolykova, E. (2011). Neobkhodimost sovershenstvovanyia obuchenyia monolohycheskomu vyskazyvanyiu na angliyskom yazyke $v$ shkole $i$ vuze [The need to improve the teaching of monologue in English at school and university]. Inostrannye yazyky v shkole. No 2. SS. 15-20. [in Russian]. 


\title{
DEVELOPING ORAL SPEECH ESSAY-REASONING SKILLS OF FUTURE FOREIGN LANGUAGE TEACHERS
}

\author{
Larysa Gron \\ $\mathrm{PhD}$ in Pedagogy, Assosiate Professor, \\ Assosiate Professor at the Department \\ of Foreign Language Teaching Methodology \\ Rivne State University for the Humanities, \\ Rivne, Ukraine \\ ORCID: 0000-0002-8115-9798 \\ e-mail: larisa.gron@gmail.com \\ Larysa Serediuk \\ $\mathrm{PhD}$ in Pedagogy, Assosiate Professor, \\ Professor at the German and French Practice Department \\ Rivne State University for the Humanities, \\ Rivne, Ukraine \\ ORCID: 0000-0001-5680-564X \\ e-mail: larisa-seredyuk@ukr.net
}

Abstract. The article deals with the problem of developing oral speech skills in the form of an argumentative essay for future foreign language teachers. The argumentative essay (essay-reasoning) is one of the most difficult communicative types of speech which requires a self-written plan for the topic, the ability to give the own arguments and assessments of events.

It is noted that in the competence approach to learning, oral coherent logical speech is one of the important components of special (language) professionallyoriented training of future foreign language teachers.

In the article the essay-reasoning is considered as a complex speech ability to motivate the interlocutor to certain actions and convince him of something; provide evidence "for" or "against" a certain action/facts; to speak and think independently, creatively, critically and reflect on given topics; as a means of activating students oral foreign language communicative activity.

The concept of "monologue- argumentative essay", its main compositional (introduction, main part and conclusion) and linguistic characteristics, stages of organizing the process of developing oral speech skills in the form of argumentative essay have been analyzed.

The introduction is recommended to begin with a general presentation of the topic of the essay, with a sentence expressing its contradictory nature. The main part of the argumentative essay is the actual description of the arguments "for" and "against" or a logical statement of the own opinion. The conclusion in the argumentative essay summarizes and reflects the content of the topic.

Operation algorithm and a set of exercises for teaching oral essay-reasoning which will help to intensify the process of developing oral argumentative statement skills of future foreign language teachers have been suggested.

Keywords: foreign language oral speech competence, monologue speech, argumentative essay (essay-reasoning), stages of developing essay-reasoning skills, complex of exercises.

Стаття надійшла до редакиіï 15.03. 2021 p. 